\title{
Liquidity and Profitability Analysis of Non-Financial Entities Listed on the Macedonian Stock Exchange
}

\author{
Dusica Stevcevska Srbinoska \\ School of Business Economics and Management, University American College Skopje \\ Blvd. III Makedonska Brigada 60, 1000 Skopje, R. Macedonia
}

Tel: 389-2246-3156 E-mail: dusica@uacs.edu.mk

Received: September 29, 2018

doi:10.5296/bmh.v6i2.13723
Accepted: October 26, 2018 Published: Nov. 22, 2018

URL: http://dx.doi.org/10.5296/bmh.v6i2.13723

\begin{abstract}
Liquidity management has a considerable influence on company performance. By analyzing secondary financial company data, this paper seeks to assess the correlation between liquidity and profitability. Through the use of audited annual report of 76 non-financial entities listed on the Macedonian Stock Exchange for the period 2014-2017, the study looks into the association between two traditional liquidity measures, current ratio and acid-test ratio, and three profitability measures, return on assets, return on equity and return on capital employed. Prior to embarking on the statistical research, literature review was performed to obtain basis for the test of hypotheses. Through the use of SPSS software, the dataset comprised of 304 observations generated descriptive statistics, and was subjected to tests of normality and variable correlation testing. The empirical findings designate that liquidity and profitability depict a positive association and that the correlation between current ratio and quick ratio on one hand and ROA and ROE on the other is statistically significant. Moreover, the empirical work reveals a slow trade receivables collection across several Macedonian industries which may damage the long-term solvency of companies, especially in times of recession and economic hardship when liquid funds are a must. In conclusion, this study suggests that the liquidity-profitability relationship should be subject to further scholarship having in mind the immense importance that liquidity management has on the financial health and stability of firms.
\end{abstract}

Keywords: Liquidity, profitability, current ratio, quick ratio, ROA, ROE, ROCE, non-financial entities, Macedonian Stock Exchange 


\section{Introduction}

Investors use the financial statements of companies to analyze their potential return and the risk related to the return on their investment. Hence, accounting information is a vital segment of the financial data investors use in order to evaluate the financial strength and health of an entity. Pandey (2005) established that "financial information is needed to predict, compare and evaluate a firm's earning ability and financial position”. Accounting data are organized into reports called financial statements whereby the goal of reporting is to provide useful data that enable investors and creditors to make decisions, to enable readers to study the desired financial reports with sensible thoroughness, to unveil the company's economic resources, the related claims and events affecting these resources, to calculate the financial result of the company in correlation to a given accounting period, and to provide information of the nature and timing of cash inflows and cash disbursements (Anthony, Hawkins, \& Merchant, 2007). Therefore, users of financial statements rely on financial statement analysis when evaluating the financial capacity and strength of a firm. Financial ratios are one of the most prominent techniques for financial statement analysis. Ratios are calculated by comparing different financial statement items in order to give financial report users an insight into the position and performance of the company (Reimers, 2011; Ibenta, 2005). Liquidity and profitability are two of the most dominant indicators that are covered in the world-wide financial literature. Hence, the author will first define the terms of profitability and liquidity before taking off to exploring their inter-relatedness.

Profitability is the capability of an entity to generate financial gain or revenues in excess of costs. Harward and Upton define profitability as the aptitude to realize a return on investment (1961). Osiegbu and Nwakanma state that profitability facilitates the process of decision-making and gives directions when preparing company policies (2008). Profitability is often measured through the use of profitability and return ratios. Some of the most prominent ratios in this category are the return on assets (hereinafter ROA), return on equity (hereinafter ROE), earnings per share (hereinafter EPS), return on capital employed (hereinafter ROCE), operating profit, pre-tax profit, and net profit (Thachappilly 2009). Return ratios facilitate the evaluation of the ability of the company to provide for a return on capital invested, assets and sales.

Liquidity determines the capacity of an entity to meet financial obligations as they mature (Kester, Ruback, \& Tufano, 2005). Hence, ratios measuring liquidity relate liquid assets to claims due within one operating cycle of the company or one fiscal year. According to Reimers, liquidity measures how swiftly an entity converts its short-term assets into cash to pay off maturing obligations (2011). Given the connection with daily running of operations, both internal and external users of financial reports and analysts assess the liquidity position of companies (Bhunia, 2010). Therefore, liquidity management is focused on providing for an equilibrium between profitability and liquidity (Raheman \& Nasr, 2007). In order to better measure liquidity, companies and analysts rely on the current ratio and quick ratio or acid test as valuable indicators.

Given the opposing views in the existing literature, the primary goal of this paper is to 
examine the liquidity and profitability positions of non-financial companies listed on the Macedonian Stock Exchange. By conducting an analysis of secondary data - the audited financial reports of listed non-financial Macedonian companies, the author will seek to validate the existence of a relationship between indicators for liquidity and profitability.

In the forthcoming section, the paper will assess existing literature on liquidity and profitability the existence of a relationship between these indicators, which feeds the author with basis for this research. The third section discusses the research objectives and hypotheses, proceeding with research methodology in the fourth section, and research results in the sixth section. The paper ends with concluding remarks and recommendations made by the author.

\section{Literature Review}

In their studies, Raheman and Nasr (2007) and Eljelly (2004) found a significant negative association between working capital management and operating profitability. High liquidity may have a negative or inverse impact on company profitability which constitutes the liquidity-profitability tradeoff position evidence by accounting literature.

The research conducted by Vintila and Nenu (2016) indicated a negative association between liquidity and profitability of companies and a significant association between the inspected variables. The authors collected ten-year financial data of entities listed on the Bucharest Stock Exchange and studied the period from 2005 to 2014. Return on assets and return on equity were used as profitability measures, whereas quick ratio and current ratio stood in for liquidity.

Siame (2012) explored the effect of liquidity on the financial performance of listed South African entities for the period 2000-2009. The dissertation relied on the financial data of 120 joint stock companies and detected a negative association between profitability and liquidity whereby the liquidity position was measured by the company cash conversion cycle and concludes that proper liquidity management can enhance company profitability.

Shivakumar and Thimmaiah (2016) tested the liquidity and profitability tradeoff of Coal India Ltd using correlation and spearman's rank method. The paper covered the period from 2010 to 2015 and also encompassed liquidity performance testing. The findings pointed out that an insignificant correlation and negative association exist between liquidity and the financial performance of Coal India Ltd.

Georgieva Svrtinov, Gjorgieva Trajkovska and Koleva (2017) studied the strength and direction of the association between profitability of banks on one hand and their liquidity and capital on the other hand in the region of Southeastern Europe. Their sample encompassed the quarterly data of commercial banks from seven countries for the period 2010-2016. Following their hypotheses testing using Pearson correlation coefficient and Spearman coefficient, the authors conclude that profitability and liquidity and profitability are positively related only in Bulgaria and Slovenia, with an inverse relationship in all other countries from the sample. Moreover, only Macedonian banks depict an inverse association between bank capital and financial performance. The paper concludes that there is an overall trade-off 
between liquidity and profitability, whereas the increase of bank capital impact bank profitability in a positive manner.

Aside from studies emphasizing the trade-off or reverse relationship between the liquidity and profitability position of companies, many other researches find a lacking or even a positive association between these determinants. In this regard, in a study of food, beverage and tobacco firms listed on the Sri Lankan Colombo Stock Exchange, Elangkumaran and Karthika (2013) inspected the relationship between liquidity and profitability. The authors looked into the data of six CSE entities a period of six years from 2006 to 2012 and used current ratio and quick ratio for liquidity, earnings per share and return on assets for profitability, and degree of combined leverage for combined risk and concluded that the influence that liquidity has on profitability is rather insignificant.

Upon studying the relationship between liquidity and profitability in Pakistan focusing solely on commercial banks, Kahn and Ali (2016) found that there is a positive correlation between these two determinants. Aside from testing the overall association between liquidity and profitability, the authors examined the relationship between current ratio, quick ratio, gross profit margin, net profit margin. The analysis was conducted through the engagement of secondary data extracted from the annual reports of Habib Bank Limited for the period 2008-2014.

Njure (2014) probed the relationship between liquidity and profitability of nonfinancial firms on the Nairobi securities exchange by covering 39 listed entities. The author used the audited annual reports of the studied firms and covered the period from 2009 to 2013 and focused on calculating correlation and regression whereby return on assets was the indicator for profitability of companies while current ratio, quick ratio and the absolute liquid ratio were used as liquidity measures. The study indicated a significant positive relationship between the selected determinants.

Etale and Bingilar (2016) tested the effect that liquidity has on profitability of five food and beverage entities listed on the Nigerian Stock Exchange. The analysis relied on secondary data from the financial statements of these five companies for the period from 2011 to 2015.The multiple regression techniques suggested a significant positive association between cash ratio and quick ratio with company financial performance as measured by return on capital employed. Moreover, the researchers revealed a negative insignificant association between cash conversion cycle and profitability.

Egbide's study (2013) of the association between liquidity and profitability demonstrated a positive correlation between current ratio and liquid ratio and financial performance. Furthermore, the author discovered a statistically insignificant negative relationship between cash conversion period and profitability measured using return on capital employed ratio. The research encompassed thirty manufacturing entities listed on the Nigerian stock exchange and used their data for the period from 2006 to 2010, or 150 observations in total.

In her paper, Podilchuk (2013) explores the effect of liquidity management on company financial performance by using fixed effects regression to Ukrainian state-owned, joint stock 
and limited liability entities from the production, construction, agriculture, retail and finance segments. The author extracted the financial data of the selected enterprises for the period from 2001 to 2010 and measured the relationship between static and dynamic liquidity variables and return on assets. The results suggest a significant but positive diminishing association between current ratio and acid test ratio and company financial performance. The researcher advocates to increase short-term assets to a certain extent beyond which any supplementary growth will have an adverse effect on company profitability.

Panigrahi (2014) studied the relationship between working capital on one hand and liquidity, profitability and risk of bankruptcy on the other hand. The author examined the financial data of ACC Ltd., Indian cement manufacturer, for the period from 2000 to 2010 and learned that despite having negative working capital ACC Ltd. earned a solid return but risked its long-term creditworthiness. The Spearman's rank correlation test revealed a linear association between liquidity measured by current assets to total assets and profitability measured by the company's return on capital employed.

Using the secondary data for the period 2007-2011 of Beta Glass of Nigeria Plc and Vita Foam Nigeria Plc, both quoted in the Nigerian Stock Exchange, Ehiedu (2014) looked into the association between current ratio and profitability measured by return on assets, the correlation between quick ratio and profitability measured by return on assets, and the relationship between return on capital employed and return on assets. The study was based on "non-probability" sampling technique and correlation analysis at 10\% significance level. Ehiedu found a significant positive association between current ratio and profitability, absence of a significant correlation between quick ratio and profitability, and absence of a significant positive association between return on capital employed and financial performance. The researcher recommends that companies avoid risky liquidity policies as they may endanger the profitability position of the entity.

Bibi and Amjad (2017) also studied the association between liquidity and financial performance by examining the 2007-2011 annual reports of fifty companies listed on the Pakistani Karachi Stock Exchange. The authors measured profitability using net operating income and return on assets, liquidity using current ratio and cash gap in days and enterprise size using net sales, total assets and market capitalization. The regression analysis indicated the existence of a substantial negative association between cash gap and return on assets given the delayed Pakistani payment cycle in comparison to the operating cycle. Current ratio manifested a substantial positive association with profitability.

In his work, Vieira (2010) explored the short-term and medium-term association between liquidity and profitability by using secondary data of large global airline companies for the period from 2005 to 2008. The researcher also looked into the effect of the 2008 financial crisis on the above-stated association. The results indicated a significant direct correlation between liquidity management and financial performance in the short- and medium-term. Moreover, Vieira concludes that during the 2008 financial crisis entities professing high liquidity performed better that entities with low liquidity positions.

In his paper, Ahmad (2016) analyzed the ten-year financial data for the period 2004-2013 of 
the standard chartered bank Pakistan, the greatest international bank in Pakistan. The author measured liquidity using current ratio, quick ratio and net-working capital as determinants and denoted an insignificant direct relationship between profitability and liquidity.

Very few analyses cover the Macedonian private segment and address the issue of liquidity and company performance. Osmani and Deari (2016) looked into the financial performance of 23 listed companies for the period from 2011 to 2015. The authors divided the five years into two sub-periods - one with a positive and one with a negative GDP growth rate and concluded that the analyzed ratios did not show a statistically significant difference upon contrasting the two sub-periods. Moreover, their overall correlation analysis detected a positive association between current ratio and cash flow ratio, profit margin and return on assets, indicating that better use of own resources lessens the reliance on non-equity financing.

In another study Iloska (2014) studied the determinants that have an impact on bank profitability as measured by return on assets. Iloska engaged financial data from the entire Macedonian banking sector as represented by 17 commercial banks for the period 2008-2011. Following the regression analysis, the researcher concluded that liquidity manifests an inconsiderable influence on profitability. However, profitability of banks is inversely correlated with operating expenditures and loan-loss provisions and positively with bank size, loan rate to total assets and employee expenditures.

\section{Research Objectives and Hypotheses}

Having in mind the lack of studies about the relationship between liquidity and profitability in FYR Macedonia, the goal of this paper is to investigate the liquidity, profitability of non-financial entities listed on the Macedonian Stock Exchange. The awareness of the existence of relationship between these indicators is of outermost importance for operational and strategic planning, direction and communication not only within companies themselves, but also by outside analysts, current and potential investors. In that direction, the author will focus on examining the ensuing research aims:

1) To examine the existing literature in terms of definitions and findings in the domain of liquidity and profitability measures,

2) To explore the association between liquidity and profitability,

3) To identify and draw attention to financial position and performance determinants that need upgrading, and

4) To give directions for future studies in the domain of liquidity and profitability.

Based on the literature review presented in the second section of the paper and the research objectives, the author built the following hypotheses that will be subject to testing in this empirical research:

Hypothesis one: The correlation between liquidity and profitability is statistically significant.

Hypothesis two: The association between liquidity and profitability is negative. 


\section{Research Methodology}

This section describes the research population and the research sample, along with the data collection and statistical methods that were used for testing the hypotheses. In order to conduct this study, the author used the secondary data from a sample of entities listed on the Macedonian Stock Exchange by engaging the non-probability sampling method given the lack of certain data at the research cut-off date: the end of July 2018 (Note 1). Banks and insurance firms were excluded from the sample, as were entities with an unaudited annual financial report for 2017 and companies with negative equity. Thus, the initial figure of 107 listed entities was reduced to 76 companies that passed the selection process. In the next stage, the audited annual reports were downloaded from the official MSE web-page and were put into use. The period subject to analysis was 2014-2017, which produced a data set comprised of 304 observations.

The quantitative data processing was performed using SPSS platform. The software analysis provided appropriate descriptive evidence, including frequency, means, minimum, maximum, and standard deviations, along with test data in the form of Shapiro-Wilk test for normality and Spearman rank-order correlation coefficient.

The following table provides the definitions behind the variables used in this research.

Table 1. Definition of the variables used in the statistical modeling

\begin{tabular}{|c|c|c|c|}
\hline Variables & & Variable Name & Variable Definition \\
\hline \multirow[t]{2}{*}{ Independent } & Liquidity & Current Ratio (CR) & Current Assets / Current Liabilities \\
\hline & Liquidity & Quick Ratio (QR) & $\begin{array}{l}\text { (Current Assets }- \text { Inventories) / Current } \\
\text { Liabilities }\end{array}$ \\
\hline \multirow[t]{3}{*}{ Dependent } & Profitability & Return on Assets (ROA) & Net Income / Total Assets \\
\hline & Profitability & Return on Equity (ROE) & Net Income / Total Equity \\
\hline & Profitability & $\begin{array}{l}\text { Return on Capital Employed } \\
\text { (ROCE) }\end{array}$ & $\begin{array}{l}\text { Operating Income / (Long-term Liabilities + } \\
\text { Total Equity) }\end{array}$ \\
\hline
\end{tabular}

Source: Reimers (2011).

\section{Research Results}

The research results are presented in this section.

\subsection{Descriptive Statistics}

As explained in the introduction to his section, the empirical research encompassed 76 non-financial entities listed on the Macedonian Stock Exchange. Table 2 provides a classification of the companies according to operations type. The table denotes that the majority of companies operate in the manufacturing sector. 
Table 2. Company classification according to industry

\begin{tabular}{lllll}
\hline & & & & Cumulative \\
& Frequency & Percent & Valid Percent & Percent \\
\hline Manufacturing & 176 & 57,0 & 57,0 & 57,0 \\
Merchandising & 32 & 10,0 & 10,0 & 68,0 \\
Services & 96 & 31,0 & 31,0 & 100,0 \\
Total & 304 & 100,0 & 100,0 & \\
\hline
\end{tabular}

Source: Own processing.

Table 2 indicates that 57 percent of companies operate in the manufacturing industry, 31 percent belong to the service sector, while the remaining 10 percent are in merchandising.

Table 3 provides a summary of the descriptive statistics behind the variables employed in the econometric models.

Table 3. Descriptive statistics on the variables used in the statistical models

\begin{tabular}{|c|c|c|c|c|c|c|}
\hline & & Current Ratio & Quick Ratio & ROE & ROA & ROCE \\
\hline \multirow{2}{*}{$\mathrm{N}$} & Valid & 304 & 304 & 304 & 304 & 304 \\
\hline & Missing & 0 & 0 & 0 & 0 & 0 \\
\hline Mean & & 4.23 & 3.19 & .01 & .02 & .03 \\
\hline Std. Deviation & & 7.60 & 6.21 & .19 & .07 & .17 \\
\hline Minimum & & .12 & .06 & -2.38 & -.33 & -2.35 \\
\hline Maximum & & 61.63 & 51.67 & .51 & .48 & .56 \\
\hline
\end{tabular}

Source: Own processing.

While current ratio manifests a higher mean of 4.23 as opposed to a mean of 3.19 for the acid-test ratio, ROE has a mean value of 0.01 . ROA's mean is 0.02 , which is below the mean value for ROCE (i.e. 0.03). The largest standard deviation is present in the current ratio, whereas the lowest standard deviation is visible on ROA. The differences arising in the mean values of ROCE, ROE and ROA indicate that different entities have dissimilar capital structures and investment patterns.

Current ratio and quick ratio, standard traditional instruments for measuring the liquidity position of companies, depict large oscillations from their mean values of 4.23 and 3.19 respectively and reach maximum values of 61.63 and 51.67 respectively. These values are achieved in companies and periods following major ownership or prior to customer restructuring of entities, thus producing a large impact on the receivables balances. Namely, one current ratio outlier stands out in year 2014 as the last year before a radical change was implemented in the customer structure of a major manufacturing company (i.e. ceasing cooperation with deficient payers and moving on to responsible customers). The other liquidity outlier marks year 2015 when a merger event took place in one of the biggest Macedonian manufacturing entities and resulted with the take-over of a large trade receivables base. 


\subsection{Hypotheses Testing}

Before deciding whether to apply parametric or non-parametric hypotheses test tools, the core assumption on data distribution will be checked: data normality. A normal distribution of the dataset means that the peak is in the middle of the histogram, whereas the remainder of the data is symmetrically distributed about the mean. Table 4 displays the test that checked whether the data used in this study is normally distributed.

Table 4. Tests of normality

\begin{tabular}{lllllll}
\hline & \multicolumn{5}{l}{ Kolmogorov-Smirnov $^{\mathrm{a}}$} & \multicolumn{4}{l}{ Shapiro-Wilk } \\
\cline { 2 - 7 } & Statistic & $\mathrm{df}$ & Sig. & Statistic & $\mathrm{df}$ & Sig. \\
\hline Current Ratio & .303 & 304 & .000 & .502 & 304 & .000 \\
Quick Ratio & .323 & 304 & .000 & .490 & 304 & .000 \\
ROA & .199 & 304 & .000 & .747 & 304 & .000 \\
ROE & .286 & 304 & .000 & .423 & 304 & .000 \\
Return on Capital Employed & .257 & 304 & .000 & .421 & 304 & .000 \\
\hline
\end{tabular}

a. Lilliefors Significance Correction

Given that the sample size of 304 observations is below the required dataset size for Kolmogorov-Smirnov testing, the Shapiro-Wilks test is used to analyze data normality. As $p$ is below the 0.05 level of significance for the research variables selected, the assumption that the data are normally distributed is rejected and a non-parametric test, the Spearman correlation analysis, is engaged as a non-paracontinuous-level alternative to Pearson's Bivariate Correlation.

Table 5. Correlation analysis: Hypothesis 1 and Hypothesis 2

\begin{tabular}{|c|c|c|c|c|c|c|c|}
\hline & & & $\mathrm{CR}$ & QR & ROA & ROE & ROCE \\
\hline \multirow[t]{15}{*}{ Spearman's rho } & \multirow[t]{3}{*}{$\mathrm{CR}$} & Correlation Coefficient & 1.000 & $.928^{* *}$ & $.245^{* *}$ & $.145^{*}$ & -.034 \\
\hline & & Sig. (2-tailed) & . & .000 & .000 & .012 & .556 \\
\hline & & $\mathrm{N}$ & 304 & 304 & 304 & 304 & 304 \\
\hline & \multirow[t]{3}{*}{ QR } & Correlation Coefficient & $.928^{* *}$ & 1.000 & $.271^{* *}$ & $.170^{* *}$ & -.044 \\
\hline & & Sig. (2-tailed) & .000 & . & .000 & .003 & .443 \\
\hline & & $\mathrm{N}$ & 304 & 304 & 304 & 304 & 304 \\
\hline & \multirow[t]{3}{*}{$\overline{\mathrm{ROA}}$} & Correlation Coefficient & $.245^{* *}$ & $.271^{* *}$ & 1.000 & $.973^{* *}$ & $.834^{* *}$ \\
\hline & & Sig. (2-tailed) & .000 & .000 & . & .000 & .000 \\
\hline & & $\mathrm{N}$ & 304 & 304 & 304 & 304 & 304 \\
\hline & \multirow[t]{3}{*}{$\mathrm{ROE}$} & Correlation Coefficient & $.145^{*}$ & $.170^{* *}$ & $.973^{* *}$ & 1.000 & $.872^{* *}$ \\
\hline & & Sig. (2-tailed) & .012 & .003 & .000 & . & .000 \\
\hline & & $\mathrm{N}$ & 304 & 304 & 304 & 304 & 304 \\
\hline & \multirow[t]{3}{*}{ ROCE } & Correlation Coefficient & -.034 & -.044 & $.834^{* *}$ & $.872^{* *}$ & 1.000 \\
\hline & & Sig. (2-tailed) & .556 & .443 & .000 & .000 & . \\
\hline & & $\mathrm{N}$ & 304 & 304 & 304 & 304 & 304 \\
\hline
\end{tabular}

**. Correlation is significant at the 0.01 level (2-tailed).

*. Correlation is significant at the 0.05 level (2-tailed). 
The hypotheses test results are presented in Table 5 whereby Spearman's correlation expresses the strength of linkage between the selected variables in a single value between -1 and +1 otherwise known as the correlation coefficient. If the coefficient value bears a positive sign, then the association between the two variables tested is positive: as variable one grows, variable two grows as well. Should the correlation coefficient express a value of zero then it can be concluded that there is no association between the variables.

The Spearman rank correlation results denote a statistically significant positive relationship between liquidity and profitability, which is analyzed on two levels. Firstly, Spearman's rho is calculated for the relationship between current ratio on one hand and return on assets, return on equity and return on capital employed on the other. Then, the existence of liquidity-profitability linkage is tested by pairing quick ratio on one hand with ROA, ROE and ROCE individually.

When analyzing the association between current ratio (CR) and return on assets (ROA), Spearman's correlation coefficient, $r s$, is 0.245 , and it is statistically significant $(p<.000$ whereby correlation is significant at the 0.01 level). Current ratio and return on assets have a positive correlation, and so do current ratio and return on equity (ROE) whereby $r s$, is 0.145 , and it is statistically significant ( $p=.012$ whereby correlation is significant at the 0.05 level). The relationship between $\mathrm{CR}$ and $\mathrm{ROE}$ is positive, albeit mildly. Only the relationship between current ratio and return on capital employed manifests a negative correlation, but with a minor strength, given that $r s$ has a value of -0.034 . However, the correlation between these two variables is statistically insignificant given that $p=.556$.

Then Spearman's rank-order correlation was run to establish the existence of an association between 304 observations for quick ratio with the same observation count for the selected profitability measures employed in this study: ROA, ROE and ROCE. The test denotes a positive correlation between quick ratio as liquidity variable and ROA as financial performance measure whereby Spearman's correlation coefficient, $r s$, is 0.271 , and it is statistically significant $(p<.000$ whereby correlation is significant at the 0.01 level). The correlation between $\mathrm{QR}$ and ROE is also positive and statistically significant given that $r s$ has a value of 0.170 and $p=.003$ (correlation significant at the 0.01 level). Lastly, the relationship between quick ratio and ROCE is marginally inverse, but statistically insignificant given the result of -0.044 for Spearman's correlation coefficient and $p$ of 0.443 .

\section{Conclusion}

The literature assessment presented in section two of this paper indicates that the importance of liquidity management cannot be denied. The deficiency or overabundance of liquid assets can endanger company financial performance. Given the opposing views regarding the correlation between liquidity and profitability in many global empirical studies, accompanied by a lack in thorough research of secondary data of non-financial entities listed on the Macedonian Stock Exchange, the author decided to analyze the positions of these two crucial performance measures for the period 2014-2017.

The statistical tests indicate that there is a statistically significant relationship between 
liquidity and profitability and that these two measures are positively correlated. Given the supporting evidence presented in Table 5 of the paper, hypothesis one that asked for probing of the statistical significance of the relationship can be accepted, whereby hypothesis two claiming that the relationship between liquidity and profitability is negative is rejected. Namely, Spearman's correlation coefficient revealed that both traditional liquidity variables, current ratio and acid-test ratio, are positively and statistically significantly correlated with return on assets and return on equity as profitability measures. These results that support the existence of a positive relationship are consistent with the empirical evidence of the studies conducted by Etale and Bingilar (2016), Njure (2014), Panigrahi (2014), Egbide (2013), Podilchuk (2013) and many others. Moreover, the current study confirms the efficient management of liquid assets by non-financial companies listed on the Macedonian Stock Exchange for the goal of achieving a better profitability. Therefore, liquidity management should not be circumvented, especially seeing that many of the listed entities are facing slow movement in the collection of their trade receivables, a prevailing trend which may harm their long-term financial stability and ability to generate profits. The set-up of a credible credit sales policy will have a positive impact of the dynamic measures of liquidity and reduces risks for companies.

This study also has certain limitations. To start with, the findings cannot be generalized to the entire Macedonian private sector unless non-listed enterprises are also taken into account. Moreover, the financial industry has been excluded from the existing analysis. Finally, in order to land on a more reliable relationship between the variables subject to testing, the data source needs to go beyond the territory of Macedonia, FYR and encompass countries from a wider region.

\section{References}

Ahmad, R. (2016). A Study of Relationship between Liquidity and Profitability of Standard Charterd Bank Pakistan: Analysis of Financial Statement Approach. Global Journal of Management and Business Research: C Finance, 16(1), 76-82.

Anthony, R. N., Hawkins, D. F。, \& Merchant, K. A. (2007). Accounting: Text and Cases (12th ed.). Boston: McGraw Hill.

Bhunia, A. (2010). A trend analysis of liquidity management efficiency in selected private sector Indian steel industry. International Journal of Research in Commerce and Management, 1(5), 9-21.

Bibi, N., \& Amjad, S. (2017). The Relationship between Liquidity and Firms' Profitability: A Case Study of Karachi Stock Exchange. Asian Journal of Finance \& Accounting, 9(1), 54-67. https://doi.org/10.5296/ajfa.v9i1.10600.

Block, S. B., \& Hirt, G. A. (2000). Foundations of Financial Management (9th ed.). Boston: McGraw Hill.

Egbide, B. C. (2013). Liquidity Management and Profitability of Manufacturing Companies in Nigeria. IOSR Journal of Business and Management (IOSR-JBM), 9(1), 13-21. 


\section{I Macrothink}

Business and Management Horizons

ISSN 2326-0297

2018, Vol. 6, No. 2

Ehiedu, V. C. (2014). The Impact of Liquidity on Profitability of Some Selected Companies: The Financial Statement Analysis (FSA) Approach. Research Journal of Finance and Accounting, 5(5), 81-90.

Elangkumaran, P., \& Karthika, T. (2013). An analysis of liquidity, profitability and risk-A study of selected listed food, beverage and tobacco companies in Sri Lanka. Proceedings of the Third International Symposium, SEUSL: 6-7 July 2013, Oluvil, Sri Lanka.

Eljelly, A. (2004). Liquidity-Profitability Tradeoff: An empirical Investigation in an Emerging Market. International Journal of Commerce and Management, 14(2), 48-61. https://doi.org/10.1108/10569210480000179

Etale, L. M., \& Bingilar, P. F. (2016). Liquidity Management and Profitability: A Study of Selected Food and Beverage Companies in Nigeria. International Journal of Management Sciences, 7(4), 217-225.

Ferati, R., \& Ejupi, E. (2012). Capital Structure and Profitability: The Macedonian Case. European Scientific Journal, 8(7), 51-58.

Georgieva Svrtinov, V., Gjorgieva Trajkovska, O., \& Koleva, B. (2017). Dpes Liquidity and Bank Capital Affets Commercial Banks Profitability? Evidence from Countries of Southeast Europe. International Scientific Conference: Contemporary Approaches in the Analysis of Economic Performances. Faculty of Economics, University of Nis, 11-12 October 2017, 243-250.

Harward, M., \& Upton, K. (1961). Introduction to Business Finance. New York: McGraw Hill.

Ibenta, N. S. (2005). Investment Analysis and Financial Management Strategy. Enugu: Institute for Development Studies, pp. 346-358.

Iloska, N. (2014). An Analysis of Ban Profitability in Macedonia. Journal of Applied Economics and Business, 2(10), 31-50.

Kester, W. C., Ruback, R. S., \& Tufano, P. (2005). Case Problems in Finance (12th ed.). Boston: MsGraw Hill.

Khan, R. A., \& Ali, M. (2016). Impact of Liquidity on Profitability of Commercial Banks in Pakistan: An Analysis on Banking Sector in Pakistan. Global Journal of Management and Business Research, 16(1), 53-59.

Njure, K. C. (2014). The Relationship between Liquidity and Profitability of Nonfinancial Companies Listed in Nairobi Securities Exchange. Master Thesis, University of Nairobi.

Osiegbu, P. I., \& Nwakanma, C. (2008). Financial Management. Port Harcourt: Harey Publications Company, p. 156 and 171. Oxford Dictionary of Accounting (3rd ed.).

Osmani, R., \& Deari, F. (2016). Firms' financial performances and economic recession: evidence from Macedonian listed companies. Bulletin of the Transilvania University of Braşov Series V: Economic Sciences, 9(58), 201-210. 


\section{Macrothink}

Business and Management Horizons

ISSN 2326-0297

2018, Vol. 6, No. 2

Pandey, M. I. (2005). Financial Management (9th ed.). New Delhi: Vikas, Publishing House put Limited, p.35 and 368.

Panigrahi, A. K. (2014). Relationship of working capital with liquidity, Profitability and solvency: A case study of ACC limited. Asian Journal of Management Research, 4(2), 308-322.

Podilchuk, Z. (2013). Impact of Liquidity Management on Profitability: Evidence from Ukraine. Master thesis, Kyiv School of Economics.

Raheman, A., \& Nasr, M. (2007). Working Capital Management and Profitability- Case of Pakistani Firms. International Review of Business Research Papers, 3(1), 279-300.

Reimers, J. L. (2011). Financial Accounting: A Business Process Approach (3rd ed.). New Jersey: Pearson Prentice Hall.

Shivakumar \& Thimmaiah, N. B. (2016). Working Capital Management-Its Impact on Liquidity and Profitability-A Study of Coal India Ltd. International Journal of Research-Granthaalayah, 4(12), 178-187. https://doi.org/10.5281/zenodo.223836

Siame, C. (2012). The Relationship Between Profitability and Liquidity in South African Listed Firms. Master Thesis, University of Cape Town.

Thachappilly, G. (2009). Profitability Ratios Measure Margins and Returns: Profit Ratios Work with Gross, Operating, Pretax and Net Profits. Journal of profitability ratio measure margin and return.

Vieira, R. S. (2010). The relationship between liquidity and profitability: An exploratory study of airline companies between 2005 and 2008. Master thesis, Umeå University.

Vintila, G., \& Nenu, E. A. (2016). Liquidity and Profitability Analysis on the Romanian Listed Companies. Journal of Eastern Europe Research in Business \& Economics. https://doi.org/10.5171/2016.161707

\section{Note}

Note 1 . The audited financial reports of listed entities can be downloaded using the following link: https://www.seinet.com.mk/ShowLayoutDocs.aspx?Layout=DOC_12304

\section{Copyright Disclaimer}

Copyright for this article is retained by the author(s), with first publication rights granted to the journal.

This is an open-access article distributed under the terms and conditions of the Creative Commons Attribution license (http://creativecommons.org/licenses/by/4.0/). 